\title{
Howland Award Presentation to Barton Childs
}

\author{
CHARLES R. SCRIVER
}

Montreal Children's Hospital, McGill University, Montreal, Quebec, Canada

Relatives and peers of Barton Childs know their man and today they celebrate his Howland Award. But there are others who might well say: Barton who? That they could do so, identifies a man who "has shunned glamor and self-importance"-to use his own phrase about the late Harry Gordon, an earlier recipient of the Howland Award. Yet Dr. Childs is surely not that unknown. The Society invited him to launch its Centennial Symposium last year (on May 13, 1988) knowing who it needed for the job. On that day, however, there were almost certainly more persons in the audience making their first acquaintance of Barton Childs than there were of those who knew him well. That fact indicates the need here of some biography.

The barest outline-and that is all Barton will tolerate-finds him: born in 1916; graduated B.A. from Williams College in 1938; M.D. from Johns Hopkins in 1942; on active military duty overseas from 1943 to 1946; thereafter completing his pediatric training at the Harriet Lane; then joining the Faculty of Johns Hopkins; appointed Markle Scholar (for 5 y) in 1953; remaining at Hopkins until his retirement in 1981-at which time he was honored with Emeritus Professorships in both Pediatrics and Biology. The tempo of his work at the "place of business," as he calls it, is no different today than when he was a full-time professor in two faculties. That could mean he is rather dormant as expected of retired folk, or that he remains active as ever. The evidence gathered by those who monitor this sort of thing, and only evidence will do for Barton Childs, favors the latter view: Barton $i$ busy thinking and he will bear evidence of that, I am certain, in his acceptance speech.

What has he done to merit nomination? To answer this simple question is not a simple undertaking. Barton is one of those who has lived the rather lonely life of a pioneer. But he will be remembered by thoughtful students of medical science long after his achievements have conferred on him the anonymous immortality that is the lot of most great men. The achievements are properly ascertained by applying to his career two aphorisms attributed to Immanuel Kant:

What can I know?

On the basis of that knowledge, what ought I do?

What Barton Childs knows constitutes more about human and medical genetics than most of us, his supporters, probably know together. Dr. Childs began to know a lot about medical and human genetics 30 years ago, in the same year Watson and Crick announced the structure of the DNA molecule. Barton was a Fellow of the Commonwealth Fund at the Galton Laboratory, University College, London in that year. His work then, and in the years following, earned for him the E. Mead Johnson Award for Pediatric Research in 1959. The sustained excellence of his broad view of human and medical genetics later brought him the Allan Award from the American Society of Human Genetics in 1973, and its Presidency in 1976.

A series of papers on glucose-6-phosphate dehydrogenase deficiency yielded a landmark, and now classic, paper in 1963. This famous study done with Ron Davidson and Harold Nitowsky, was the first to give evidence of the Lyon hypothesis at the molecular level. Glucose-6-phosphate dehydrogenase deficiency was not his only interest and there are other famous papers in his bibliography; e.g. the initial descriptions of ketotic hyperglycinemia, written when he and Nyhan were on the faculty together at Hopkins. In recent years, his questing intellect has examined the impact of genetic counseling and genetic screening on individuals and families; and before retirement, he had ventured perceptively and imaginatively into the genetics of behavior, choosing reading disabilities as his probe into these murky waters. It is of passing interest that his research was supported by the same RO-1 grant for 30 consecutive years-surely something of a record in the art of getting and holding an NIH grant.

The specific research is as varied and solid as any could wish. Yet it is the larger view that commands even greater respect. Childs has used particular observations to develop and supply a more universal view of health and disease. Few, if any, have a better understanding of the biologic basis of disease in man. Like Socrates, he has been asking questions that discomfit us. His questions are as likely to be about the patients who have disease as about the diseases they have. They cover a lot of ground: Why is there a deviant sex ratio for sepsis and meningitis in the modern North American newborn? Why are the most obvious genetic diseases also "pediatric diseases"? What do we mean by genetic heterogeneity? Can we treat-meaning cure-a patient with a genetic disease?

His papers in this vein are not always comfortable reading: they amaze by their immense scholarship, they temper our selfesteem by showing what we do not know. At the same time, these articles inspire: they indicate research and experiments yet to be done; they inform; they shake us out of intellectual ruts; and they are written in a prose style that pleases. If I could escape temporarily to a desert island to escape intrusions, I would take some of Barton's writings with me: Genetics and metabolism, The E. Mead Johnson Award Address (1); The genetic origin of some sex differences among human beings (2); Genetic heterogeneity (3); Garrod's conception of chemical individuality (4); A place for genetics in health education and vice versa (5); Human behaviour genetics (6); Persistent echoes of the nature-nurture argument (7); A biologic point of view-(for its amusing invocation of the snail darter controversy) (8); One approach to scientific literacy (in the context of his abiding interest in education) (9); The causes of hypertension (for its unusual insight on how to investigate the causes of a common disease) (10) and the vindication of those ideas in a recent paper on a DNA marker for essential hypertension in a rat model (11); and recently, his spirited adumbration of the place for molecular genetics in medicine (12). After rereading this or any other sample of almost four decades' worth of medical and human genetics according to Childs I would be inspired to return as quickly as possible to my own place of business, and to work with renewed energy and enthusiasm. Meanwhile, Barton Childs is still at work doing what he does best: applying his mind to the problems of medicine. As evidence on any day of the week one will find the manuscript for his magnum opus on Medical Genetics growing in form; and this month, his book (with Scriver) on Archibald Garrod's Inborn Factors in Disease was published by Oxford Press.

If through reading we can partially answer the question "what does Childs know?" we can then ask: "what did he do with that 
knowledge?" The record shows many memberships on committees, councils, advisory boards, and foundations-the reports and activities of which reflect some of the applications of his knowledge and wisdom. One example will suffice. For $3 \frac{1}{2}$ years, between 1972 and 1975, he chaired the Committee of the National Academy of Science/National Research Council convened to examine the issues in genetic screening. The report of that Committee addressed principles, practice, and research in genetic screening. It is a cornerstone of modern thinking about this important new activity in medicine and it is used by everyone required to deal with the subject in any of its forms. (Hardly anyone knows how carefully Childs shaped this vastly influential document or that he was its principal author.)

Barton Childs' influence as a teacher is again subtle. The classroom and textbooks are not his favorite arenas. His influence is occasionally felt still at the bedside, sometimes at morning report on service, more often in the offices and laboratories of fellows and colleagues, and daily in the seminar or coffee room. There is no grand display of knowledge, none of the oneupmanship that passes for erudition here. We encounter mainly the simple question that precisely punctures an inflated hypothesis or rhetoric. It is not a style for the insecure. But those who survived the experience have gone on to become thoughtful members of pediatric faculties across the nation and around the world.

If we understand better why our patients today are more likely to have a disease with a genetic component of cause than was the case in the past, if we have learned more precisely how to predict, avoid, and prevent disease through the application of genetic principles, it is because Barton Childs asked of himself and others, to an extent that we may scarcely realize: What can
I know and what ought I do with my knowledge? There is another quotation that fits Barton Childs as aptly. Accordingly, it is a good conclusion to these comments. It is by Montaigne who said:

"If my mind could gain a firm footing, I would not make essays, I would make decisions; but [my mind] is always in apprenticeship and on trial."

Please stand, Barton Childs, and in receiving the Howland Award in 1989, know you are not on trial, are recognized as one of medicine's great apprentices, and, by your contribution to pediatrics, have aided its advancement.

\section{REFERENCES}

1. Childs B 1960 E. Mead Johnson Award Address: genetics and metabolism. Pediatrics 25:565-571

2. Childs $B 1965$ The genetic origin of some sex differences among human beings. Pediatrics 35:798-812

3. Childs B, Der Kalowtian VM 1970 Genetic heterogeneity. N Engl J Med 279:1205-1212; 1267-1274

4. Childs B 1970 Garrod's conception of chemical individuality. N Engl J Med 282:71-77

5. Childs B 1974 Allan Memorial Award Lecture: a place for genetics in health education and vice versa. Am J Hum Genet 26:120-135

6. Childs B, Finucci JM, Preston MS, Pulver AE 1976 Human behaviour genetics. Adv Hum Genet 7:57-97

7. Childs B 1977 Persistent echoes of the nature-nurture argument. Am J Hum Genet 29:1-13

8. Childs B 1980 A biological point of view. Biol Sci Curr Study J 3:10-14

9. Childs B, Hickman F 1983 Human genetics: one approach to scientific literacy. Daedalus 112:189-210

10. Childs B 1983 Causes of essential hypertension. Prog Med Genet 5:1-34

11. Rapp JP, Wang SM, Dene H 1989 A genetic polymorphism in the renin gene of Dahl rats cosegregates with blood pressure. Science 243:542-544

12. Childs B 1987 Introduction, molecular genetics in medicine. Prog Med Genet $7: 1-16$ 